\title{
ビールの醸造研究と地ビール業界への 貢献
}

本稿は, 著者がこれまで行ってきた, 海洋酵母や北海道産大麦を用いたビール醸造, ナガイモ等の各種原 料を用いた発泡酒醉造についての研究, 並びに地ビール産業に対する考え方を述べたものである。

著者が述べているように, 地ビールを中心とした地域の食文化が醸成され, 地ビール産業が発展すること を期待したい。

永島 俊夫

平成 6 年, 政府の規制緩和による酒税法の改正によ り，ビールの年間最低製造数量は 2,000 キロリットル から 60 キロリットルに引き下げられ, 各地で地ビー ル会社が設立されるようになった。ちようどその時期 に東京農業大学生物産業学部（北海道網走市）ではビ ールの試験醸造装置を設置し，税務署よりビールおよ び発泡酒の試験醸造免許を取得して, これまでに地域 の各種原料を用いた醸造試験を行ってきたので, その 概要と今後の地ビール産業に対する私の考えについて 紹介させていただくことにした。

\section{1. 大学におけるビール醸造の研究と網走ビール 株式会社の設立}

キャンパスが位置する北海道オホーツク地域は大規 模な畑作農業が盛九で，大麦，小麦の産地である。そ のような立地条件を生かして網走市からの依頼もあり, 東京農大ではこれらの地元の豊富な原料を利用したビ ールの醸造試験を開始した。実験室規模での基礎研究 を経て本格的に研究を進めるため, 平成 7 年 3 月, 学 部に 100 リットル規模のビールの試験醸造装置（写真 1）を設置し, 税務署よりビールおよび発泡酒の試験 醸造免許を取得した。これにより大学で小プラント規 模での醸造研究ができるようになり, キャンパスの周 囲で収穫される地元の大麦や小麦を用いて各種醸造条 件の検討を行うとともに，副原料として馬鈴薯，トウ モロコシ, カボチャ, 果実類などを用いてビール, 発
泡酒の醸造試験を重ねてきた。また, 当時は各地で地 ビール会社が設立されており, 各地の原料を用いた試 験醸造の依頼や醸造技術者の養成ということも求めら れ, 各地ビール会社からの要望にも対応してきた。特 にこの規模の試験機は本製造の10 分の 1 程度の規模 で醸造ができるため, 地ビール会社の試作機としても 適した規模であり，各社からの試験依頼が寄せられた。

大学のこのような取組みを知った網走市民は, 地元 の大学の支援が得られるのだから, 何とかこの地にも 地ビール会社を作りたいという機運が高まっていき， 網走市民有志による地ビール研究会が組織された。研 究会において定期的に協議を重ねた結果, 地元経済人 が出資して平成 10 年に網走ビール株式会社が設立さ



写真 1 ビールの試験醸造装置

Study on Beer Brewing and Contribution for Craft Beer Industry Toshio Nagashima (Faculity of Bioindustry Tokyo University of Agriculture) 
れた。この会社は「地元の原料，地元の技術，地元の 資本」ということをキャッチフレーズに，大学が技術 的支援をする全国でも例のない地ビール会社として注 目されている。製品は通常のエール，ヴァイツゼン， ピルスナーのほかに, 大学と地域の連携により開発さ れた，地域の特産物を副原料としたビール，発泡酒の 醸造を行い, 話題も多い。

\section{2. 海洋酵母によるビールの醸造}

大学でのビール醸造を知った企業や試験所からの研 究依頼なども寄せられ，それについての対応を行って きた。そのうちの 1 つの例として, 三共株式会社から の委託研究がある。同社では海から分離した発酵力の 強い酵母を用いて，すでに清酒やワインなどの䁔造を 行い製品化していたが1)，これをビールに使えないか ということで，委託を受けて試験を行った。同社が分 離した 13 種類の醳母を用い, まずこれらの麦汁にお ける発酵度について調べたところ，2種類を除く 11 種類の酵母はビール醸造工程に扔いて十分に発酵する ことが認められた。そこでこれらの発酵後における成

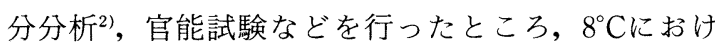
る発酵では Y 1095，Y 1160，Y 1167，15ㄷ発酵で は Y 990，Y 997，Y 1095 の各酵母が良好であること が明らかとなった。さらにその中から官能評価で良好

第 1 表 試験醸造製品の成分

\begin{tabular}{|c|c|c|}
\hline & $\begin{array}{l}\text { Y } 1095 \\
\left(8^{\circ} \mathrm{C}\right)\end{array}$ & $\begin{array}{l}\text { Y } 990 \\
\left(15^{\circ} \mathrm{C}\right)\end{array}$ \\
\hline 比重 & 1.012 & 1.012 \\
\hline $\mathrm{pH}$ & 4.62 & 4.44 \\
\hline 酸度 $(\mathrm{ml} / 100 \mathrm{~g})$ & 26.6 & 22.6 \\
\hline 全糖 (\%) & 3.8 & 2.3 \\
\hline 還元糖 (\%) & 1.0 & 0.6 \\
\hline 全窒素 (mg \%) & 64.8 & 70.2 \\
\hline ホルモール態窒素 (mg \%) & 17.6 & 21.2 \\
\hline 色度 & 8.6 & 9.6 \\
\hline 苦味価 & 12.1 & 14.7 \\
\hline アルコール度 (\%) & 4.0 & 4.5 \\
\hline 原麦汁エキス (\%) & 10.9 & 11.5 \\
\hline 真正エキス (\%) & 3.1 & 2.8 \\
\hline 真正発酵度 (\%) & 72.9 & 76.8 \\
\hline
\end{tabular}

であった2株（Y 1095，Y 990）を用い，100リット ル規模の試験醸造を行い, いずれも良好なビールが醸 造できることを確認した (第 1 表)。その後, この試 験の成果をサッポロビールが応用し, 発泡酒「空と大 地の澄んだ生」という製品が発売された。

\section{3. 北海道産大麦のビール醉造適正試験}

ビール原料としての国産大麦は，これまでにサッポ ロビールが北海道で「りょうふう」を契約栽培して使 用しているが，その他の大麦のビール醸造適正につい て, さらに詳細に調べるため, 北見農業試験場, 帯広 畜産大学との共同研究で, 北海道産大麦のビール醸造 適正試験を行った。28種類の二条大麦を北見と帯広 でそれぞれ栽培し，全部で 56 種類を試料として用い た。各試料につき, 千粒重, 吸水率, 葉芽伸長度など から最適な製麦条件を決め, 自動製麦機にて麦芽を調 製した。それぞれの麦芽についてジアスターゼ力の測 定を行うとともに, コングレス麦汁を調製してその成 分を分析した。ボーリング, 全糖, 還元糖, 全窒素, アミノ態窒素，エキス分などの值を比較したところ， 「ミハルゴールド」,「ほうしゅん」,「みょうぎ二条」, 「関東二条 31 条」, 「関東二条 32 号」, 「栃系 274 号」, 「りょうふう」など 14 品種は各成分のバランスがよく, ビール醸造に適するものと判断し, 実験室規模の醸造 試験を行った。醸造後それぞれの成分を比較するとと もに官能評価の結果などとも合わせ, 最終的に「りょ うふう」,「ミハルゴールド」,「みょうぎ二条」を選択 し，いずれも栽培地による大きな違いは認められなか ったため, 北見産の大麦を用い, 100 リットル規模の 試験醉造を行ったところ, 製品はそれぞれ良好な品質 のビールとなった。製品はー 2 点から+2 点までの 5 段階評点法により官能検査を行い, 各評点の平均值を 第1図に示した。このように，すべてのバランスとい うことを考慮すると「りょうふう」が最も優れていた。 しかし, 北海道産大麦で「りょうふう」以外にもビー ル醸造に適する品種があることが認められ，これらの 原料を配合することにより，これまでとは違う特徵を もった製品ができる可能性も示唆された。

\section{4. ナガイモを用いた発泡酒の開発}

網走市の隣に位置する東藻琴村 (現在の大空町東藻 琴）の若手農業者グループ「ノンキークラブ」から， 


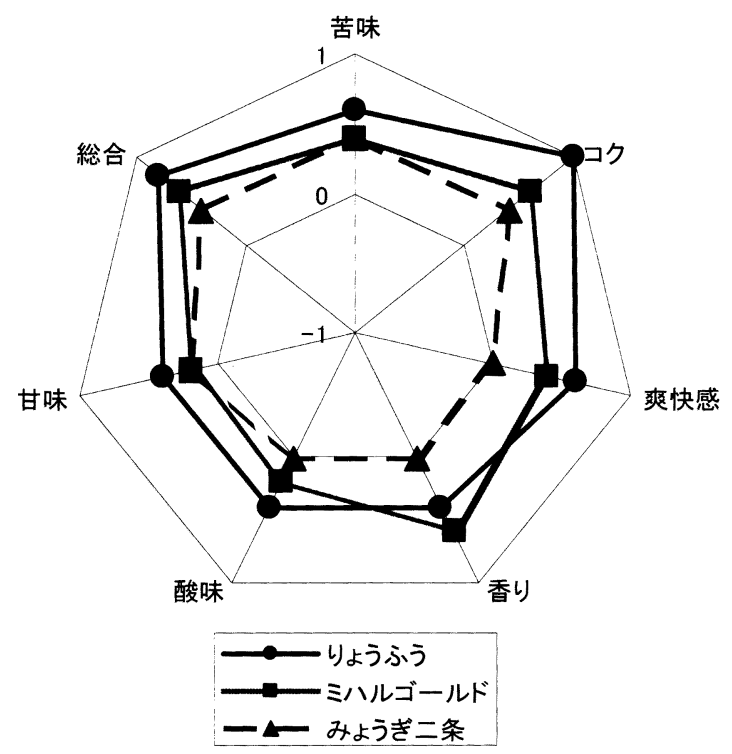

第 1 図 醸造製品の官能評価

自分たちの生産した麦を使ってビールを造りたいとい う要望があった。彼らは大麦，小麦を考えていたが， この地域はナガイモの栽培の盛んなところであるため, 特産物のナガイモも副原料として使抢うということを 提案したところ, 地域の良質な水も運ぶということに なって, ビール造りの話が盛り上がった。ビール醸造 についての勉強を少ししてもらい, 農閑期となる 12 月に大学の試験醸造装置による仕込みを行った。1月 にできた製品は早速地元に持って行き試飲会を行った。 もちろん試験醸造品なので単に皆で飲むわけにはいか ないため, 税務署に試飲会出席者の届けと趣旨の説明 をして許可を受けて実施した。その結果は大変評価が 高く, 一度限りで終わらせてしまうのはもったいない, これを何とか地域の特産品として売り出せないか, と いうことになった。種々検討した結果, 大学では試験 免許であることから実際に販売することはできないた め, 網走ビール(株)に委託して製品化し, 製品は東藻 琴村で販売するという形で実現した。地域では季節の イベントや観光客のお土産などとして, すっかり定着 している。

ナガイモを原料として用いた場合，そのデンプンを 糖質原料として利用できるが, 酵素による分解性が悪 ${ }^{4)}$, 糖化条件を検討する必要があった。しかし, 他 の芋類とは違いナガイモは癖がないことから, 製品の 風味を悪くするようなことはなく, 醸造する上の問題
点は少なかった。さらに, ナガイモの粘性は煮沸工程 により全く消失するが，その粘性成分 ${ }^{516)}$ は多糖およ び糖タンパク質であることから，完成した発泡酒の泡 に対して好影響を及ぼし, キメが細かく, 泡もちのよ い製品となった。

後日, 東藻琴村の青年グループは, 自分達の生産し た原料を用い，大学と共同で製品開発をして地域の地 ビールとして販売したという, 今回の一連の取組みに ついて, 北海道青年農業者会議でプロジェクト発表を 行い, 生活部門の最優秀賞を受賞するとともに「優秀 農業青年クラブ」にも選ばれた。

\section{5. ビール, 発泡酒の委託醸造}

地域産物を用いたビール，発泡酒の醸造は，規格外 品などの資源の有効利用ということにも貢献できる。 前述のように小麦, トウモロコシ, カボチャ, ナガイ モなど, 一次産業の盛んな地域であるために, それら は規格外となるものも多く，これらをビール，発泡酒 の原料として利用することを試み，いろいろな製品を 醸造した（第 2 図）。さらに地域で栽培しているサク ランボやマタタビなどの果実を使うことにより, 酸味 と爽快感のあるフルーツビールなどの醸造も可能であ つた。

そのような醸造試験と並行して,さらに各地の産物 を使ったビールができないか，という相談が寄せられ， ナガイモの発泡酒と同じように, 士幌町のスィートコ ーン, 陸別町のニンジンを使った発泡酒などの開発を 行い, 網走ビールで委託醸造して各地域で販売するこ とができた。このような実際例から，いずれも東京農 大で技術開発を行い, 網走ビールにその技術を提供し て醸造し, 地域で販売するという, 三者関係の地ビー ルの委託醸造システムが構築された。

今，地ビール業界は初期投資が重荷になって経営の 苦しい会社が多くなっている。このような委託醸造が できれば，各地域では全くビール醸造設備をもたずに 自分の地域の地ビールとして販売でき, 委託を受ける 地ビール会社はすべて委託先が買い取ってくれるため, 販売の手間をかけずに全く無駄なく利益が上がる。今 後このような経営方式も地ビール産業の 1 つの形とし て定着することと思われる。それには間に入って技術 開発する研究機関が必要で, 東京農大がその役割を果 たしている。 




第 2 図各種醸造製品の成分

\section{6. 地ビール産業の問題点}

平成 6 年の規制緩和により地ビール会社の設立が相 次ぎ，平成 9 年ころの最も多いときは全国で 350 社ほ どになった。しかし，立ち上げた当初はよかったがそ の後の販売量が伸びず，当初投入した設備投資がその まま重荷になり，返済できずに撤退を余儀なくされた 会社も多く見られる。

これには地ビール産業におけるいくつかの問題点が ある。まず挙げられるのは価格で，小規模生産の地ビ ールは大手会社に価格面で太刀打ちできない。また， 製品の種類は多くの地ビール会社がエール，ヴァイッ エン，ピルスナーの 3 種類で, 各地ビール会社の特徴 があまりない。これは原料や製造技術にも関係してお り，原料となる麦芽はほとんどが外国からの輸入品で あることや，釀造技術も大手ビール会社に指導を受け る場合が多く特徴が出しにくいというようなことがあ げられる。そして，思い切った試作ができないことも ある。すなわち，試験醇造するような設備をもたない ため，試作は常に本製造の一部改良のような形でやら ざるを得ない。従って, 何か変わったものをやってみ たいと思ってもなかなか実現できず，現状に留まらざ るを得ない場合が多い。

ビールの歴史は紀元前 6000 年ころから造られてい たという記録があるが7, 日本で醸造されるようにな
ったのは明治時代になってからで，まだ 100 年余りし かたっていない多。これまで日本で造られるビールは ドイツ系のピスルナータイプのビールが主体で, 日本 人はビールというとこれを指す。地ビール会社ではこ れまでにあまりなじみのなかった，エール，ヴァイツ エンなどを醸造し，ピルスナーだけでなく種類を広げ たビール，発泡酒の醇造を行うようになり，わが国に もいろいろなビールが増え, それらの定着することが 期待された。しかし，ビールはこれまでのイメージが 強く, 少し変わったビールや発泡酒はなかなか一般に は受け入れられず, 苦戦している地ビール会社も多い のが現状である。

清酒は地酒というものがあり,これは地域に定着し ている。地方へ出かけたときの大きな楽しみでもある。 それは古くからの歴史によって築きあげられた酒の文 化であるといえる。酒蔵の製造技術は杜氏によりしっ かりと守られ受け継がれて抢り, 技術者の力によると ころが大きい。地ビール会社では醸造技術は未熟な部 分がある。その技術を向上させるため経営者と一丸と なって会社の特徴を創造していくべきだろう。

\section{7. 地ビール産業のこれから}

今頑張っている地ビール会社では何らかの特徴を出 すために，地域の特産品を副原料に使うことや，醸造 法を独自に勉強するなどして努力をしているところも 
多い。これからの地ビールは地域の原料を使った，そ の地域独特の製品があってよい。ただ，前述したよう に，日本ではビールというとピルスナータイプしかイ メージにないため, このようなビール, 発泡酒はなか なか受け入れられない。しかし，地ビールはこれまで になかった味わいのビールや発泡酒を飲めるという楽 しみを広げるとともに，地域の活性化にも貢献するこ とができる。それには, 地ビール会社はもちろん, 地 域でもそれを応援していくことが大切で, 地ビールが その地域住民の誇りとなるようにしていかなくてはな らない。

地ビールは「とりあえずビール」というのではなく， それぞれの特徵あるビールを本当に楽しめるような飲 み方があるはずである。地域のビールに合う食材の提 供も大切である。地酒と同じように，「あそこに行け ばあのビールが飲める」という楽しみを与えるととも に地域の活性化にも貢献できる。そして地ビールを中 心とした地域の食文化が醸成されていくことを期待し たいものである。

<東京農業大学生物産業学部食品科学科>

\section{文献}

1）小玉健太郎：海洋酵母 Saccharomyces cer- evisiae の分離と利用, 醸協, 94 (11), 879 (1999)

2) ビール酒造組合国際技術委員会（分析委員 会)：BCOJビール分析法. 日本䁔造協会（東 京). 1998.

4）永島俊夫, 鴨居郁三：ヤマノイモ(Deoscorea）澱粉の諸性状について. 日本食品工業学 会誌. 37(2), 124 (1990)

5) Nagashima, T., Tsukui, M., Sato, H., Takano, K. and Kozima, T.: The Mechanisms of Development of Viscosity in Yam Mannan (Dioscorea opposita Thunb.) Food Preservation Science. 27 (3), 73 (2001)

6) 津久井学, 佐藤広顕, 永島俊夫, 渡部俊弘, 高 野克己，小嶋秩夫：ヤマイモの粘性糖タンパク 質の性状ならびにポリペプチド鎖の構造. 日本 食品科学工学会誌, 48(8), 578 (2001)

7）田村功訳：世界ビール大百科. 大修館書店（東 京), p. 188 (1997)

8）キリンビール株式会社：ビールのうまさをさぐ る (財団法人遺伝学普及会編集員会編). 裳華 房 (東京), p. 12 (1994) 